\title{
Perspectives on Woody Biomass Fuel Value and Specifications in Alabama
}

\section{Dana Mitchell, Research Engineer}

USDA Forest Service, Southern Research Station, Forest Operations Research Unit, 520 Devall Drive, Auburn, AL 36849-5418, danamitchell@fs.fed.us

\author{
Written for presentation at the \\ 2006 ASABE Annual International Meeting \\ Sponsored by ASABE \\ Portland Convention Center \\ Portland, Oregon \\ 9 - 12 July 2006
}

\begin{abstract}
Pulp and paper mills in Alabama buy woody biomass but the specifications required by the mills vary and are not widely known. Some characteristics of woody biomass that are often included in mill specifications include size, species, ash and moisture content. These characteristics are briefly reviewed in reference to how they impact the energy value, physical handling or processing of the material. An informal structured telephone interview was used to obtain the mill specifications and testing procedures used in some of the pulp and paper mills in Alabama. Finally, the relationships between woody biomass characteristics and the mill specifications were summarized.
\end{abstract}

Keywords. biomass, logging residue, mill specifications, energy, hog fuel 


\section{Introduction}

Increasing prices for gasoline, natural gas and other sources of energy are continuing to fuel the interest in woody biomass as a source for energy. Woody biomass can come from a variety of sources, including mill wastes, urban waste and logging residues. Approximately 5.3 million oven-dry tons (odt) of logging residue and cull trees (about 9.6 million tons of green biomass at $46 \%$ moisture content) are generated annually in Alabama as a by-product of conventional harvesting operations (Muehlenfeld, 2003). This paper provides some insight into (1) how various components of woody biomass can impact the value of fuel chips and (2) which of these components affects delivered product prices at some of the fuel chip delivery locations in Alabama.

Mill specifications for woody biomass deliveries can vary. Processes used by mills to convert woody biomass to energy often have fuel chip size requirements. For example, the size needed for co-firing with pulverized coal or natural gas may be much finer than that required for cogeneration in a wood-fired boiler. Some facilities have unique feeding mechanisms, such as conveyors or augers, that may be designed to work within a specific size range of material. Biomass delivered below a pre-determined moisture content may be worth a premium to some facilities while it may not be important to others. Therefore, prices that mills are willing to pay for biomass may by impacted by the size, moisture content, and other components of the delivered product.

\section{Properties of Woody Biomass}

Before beginning a discussion on the value of biomass and mill specifications for fuel chip (hog fuel) deliveries, it is important to understand how some of the components of woody biomass can impact the value of the delivered product. This paper considers the following characteristics of biomass: species, ash content, moisture content and size.

\section{BTU Values of Important Southern Tree Species}

Energy values, measured in British thermal units (BTUs), can vary between tree species. Loblolly pine (Pinus taeda L.) and longleaf pine (Pinus palustris M.) are two important southern pine species for the southern United States timber industry. Generally, the bark from these southern pine species has a higher heating value (about $8900 \mathrm{btu} / \mathrm{odt}$ ) than that of southern pine wood (8 600 btu/odt) (Koch, 1972). Red oak (Quercus rubra G Loomis), white oak (Quercus alba G Loomis) and hickory (Sarya ovata P Mill) are common southern hardwood species and have heating values ranging from 9360 to 9510 btu/odt in the stemwood (Ince, 1979).

\section{Ash and Impurities}

Ash is comprised of inorganic substances that remain after wood is burned (Koch, 1972). Ash generally constitutes less than 0.5 percent of oven-dry loblolly or longleaf pine stemwood (Koch, 1972). Needles of loblolly pine have been found to have an ash content of 2 percent (Metz and Wells, 1965). Although this amount seems very small, it does result in a residue after an energy conversion process. When biomass is burned in a boiler, everything that doesn't completely combust can fuse together. This non-combusted material includes impurities, such as metal, sand and plastic; and the inorganic substances from the biomass. This fused material can block the burning ports in a boiler so that the boiler doesn't heat evenly or efficiently. 
Hog fuel can include sand, dirt, concrete, plastic, metal and other contaminants. In Alabama, some land and storm clearing activities that furnish hog fuel have been known to include kitchen appliances, bicycles, metal storage buildings, fiberglass insulation and car parts in their hog fuel deliveries. These contaminants can break the "teeth" in the mill's grinder (hog).

\section{Moisture Content}

In studies referenced by Koch (1972), the moisture content in southern pine decreases with age. Proportionately, younger trees contain a higher percentage of their volume in juvenile wood as compared to mature trees. It follows that young, pre-commercial trees processed as whole-tree chips for fuelwood would produce fuel chips with a higher moisture content than those from mature trees.

\section{Size}

Fuel chips created using a chipper can produce a fairly uniform, flat chip. The size of the chip can vary based on the screen size used on the chipper. Chippers, however, are designed to produce a consistently-sized product with most material within a narrow range of dimensions. Output from grinders is typically less uniform in size and shape. Horizontal grinders can create long, thin strips and small chunks. To control the output size, screens may also be used in grinders. Tub grinders also produce a variety of non-uniform pieces.

\section{Methodology}

The Alabama Forestry Association (2006) lists 13 pulp and paper mills in Alabama. These 13 mills are owned by 12 different companies. This paper was limited to a comparison of mill specifications for hog fuel delivered to pulp and paper mills in Alabama.

In an effort to compare mill specifications, a structured interview questionnaire was developed. The questions were fashioned to gain an understanding of mill specifications, problems and product values related to the various forms and sources of hog fuel.

Procurement people at eight pulp and paper mills were contacted by telephone. Each of these mills represents a different company, i.e. no mill ownerships were sampled twice as most have the same hog fuel specifications in all of their Alabama locations. The hog fuel procurement forester at each mill was interviewed using the questionnaire to guide the discussion.

All values expressed in this paper are in terms of green tons. One company reported their numbers in oven-dry tons with an average moisture content of 45 percent. These numbers were converted to green tons for comparison purposes.

\section{Results and Discussion}

\section{Woody Biomass Use}

Total tons of hog fuel used by mills ranged from 230 to 3400 green tons/day. Total usage per day for the eight mills was 8894 tons. If these mills operate 365 days per year, the total annual consumption of wood-based fuel would be 3.2 million tons. With over 9 million tons of green biomass available annually from logging residues, the available supply from this one source of biomass is much greater than the demand from these eight mills.

Some mills have the ability to produce more energy than they need. Only one mill produced and sold excess energy to the power grid. None of the mills reported any seasonal differences 
in their usage, but one mill reported that using wood in the boilers is only preferred when the price (based on equaivalent BTU) is competitive with or less than coal.

\section{Source}

Mill residues were cited as the largest source of hog fuel deliveries. Two mills limit their deliveries of sawdust. Real estate clearing and municipal landfill material were cited as the next most important source of hog fuel, with forest residues typically listed last. One mill received most of its boiler wood in the form of bark from its own pulpwood woodyard on site.

Most surveyed foresters expressed that it is a seller's market for hog fuel. Pine sawmills, veneer mills and hardwood lumber mills are closing, causing an increase in the competition for mill residues. Other sawmills are using more and more of their own mill residue for heating their kilns, and removing even more mill residues from the market. Hardwood lumber manufacturing is seeing increased competition from Asia, reducing the availability of hardwood lumber residues. Some hardwood mills have decreased the number of shifts worked, thus decreasing the available mill residue available on the market. Private industry foresters recognize that future hog fuel may need to come from other available sources, primarily from in-woods processing of forest residues.

One mill has a new company policy to increase biomass use by 20 to 40 percent by the year 2020. If mill residues become more limited in availability, this additional biomass will need to come from urban/municipal waste and logging residue processing.

\section{Mill Specifications}

Three mills have written mill specifications. The remaining five mills reported that they had specifications, but that they were loose, and in many cases, were not in written form.

\section{Species}

Even though BTU values can vary by species, none of the mills surveyed indicated a preference for a particular species. Mixed species loads are accepted by all mills surveyed. This may reflect the reality of the difficulty of sorting forest residues by species for a relatively low-value product.

\section{Ash Content}

No mill reported having a maximum allowable ash content in its specifications for biomass. One mill is considering adding an ash content limit to its specifications, and that maximum will probably be 10 percent.

\section{Moisture Content}

Moisture content specifications ranged from "nothing too dry" to "the drier the better" to "no running water". Three mills reported maximum moisture content in deliveries between 45 to 50 percent (wet basis).

\section{Size}

Size of material accepted is variable not only because of the type of wood-fired boiler, but also due to the handling capabilities in the mill. The age of the mill facilities was highly variable with some in excess of 50 years old. Many of these mills were designed to handle chips, not hogged 
fuel. Chips flow across conveyors differently than hogged material. Sometimes the hogged material looks like a bird's nest on the conveyors and it hangs up in the gates. Some mills pull the material along on a chain and the hogged material bridges over the chains so that no material is flowing along the system and it bunches up behind the "bridge". In other mills, the handling capabilities of the reclaim area influenced the size of material accepted.

One mill reported that they require a hog fuel sample from each supplier and the only test they run is a visual on the size. This mill prefers material in a 2 to 3 -inch size and prefers chunks to sawdust, although they can accept pieces as long as 10 inches. Sawdust burns at the top of their boiler, and is wasted. Any sawdust deliveries are mixed with chunks to limit the waste.

Two mills reported an actual size specification. One required pieces to be less than 12 -inches long, and the other required the pieces to be less than 14-inches long and no more than 1-inch thick.

Seven of the eight mills surveyed regrind the biomass. Five of the mills reported that they regrind the material before it goes into the storage pile. One mill stores the biomass as it is delivered and does not regrind it until it is pulled from the pile to go to the boiler. Another mill hogs the biomass twice, once before storage and again when it is pulled from storage. The mill that only uses its own woodyard bark for boiler wood does not regrind the bark at any point.

\section{Sample Testing}

Other than the visual testing mentioned above, three mills actually test samples of delivered material. One of these mills mails samples away to be tested. Another mill performs in-house testing for moisture and ash content, but did not list a mill specification for maximum ash content. This mill also sends samples out for BTU testing. A third mill performs BTU testing inhouse and by contract. The two mills that test for BTU values use the results to determine $a$ value for the deliveries.

\section{Storage and Delivery}

Seven of the eight mills surveyed reported having at least one chip dump. Four specifically mentioned accepting sawdust deliveries in vans with moving floors to limit airborne particles. None of the mills surveyed reported having a covered storage area. Mills could store varying amounts from 500 to 20000 tons. Most mills reclaimed the hog fuel using loaders or dozers to mix piles and push material into augers.

Plastic, metal and other contaminants were frequently named as problems with hog fuel originating from urban sources. For example, people in one urban area tossed everything they owned behind a fence along the back of their property-plows, a truck and a tremendous amount of other materials. A nation-wide chain store bought the adjoining land and hired a contractor to clear it. The city had a "no burn" policy within the city limits, so the material had to be processed into hog fuel, buried, or hauled to a landfill. The contractor chose to grind up the woody debris for hog fuel. Some of this trash along the fence line was included in the hog fuel. When this material was detected on the conveyor belts at the mill, belts shut down to protect the regrind hammers. But, at this mill, the chip dump belts were run on one system, so when one belt stopped, belts on another chip dump were also stopped.

Metal detectors and magnets are commonly used to detect metals in hog fuel, but sometimes they are ineffective. If the conveyor system had a $\mathrm{V}$-shaped belt and the metal was lodged at the bottom of the "V", there could have been 10 inches of hogged material covering a piece of metal. Although the sensitivity of a detection system can be changed, adjusting it to account for this type of problem would also have detected a gum wrapper and shut the system down. 


\section{Suppliers}

All mills that bought fuel wood operated under negotiated contracts with suppliers. None accepted open gate deliveries. Mills with the lowest demand for fuel wood reported using 2 suppliers, while mills buying larger amounts of fuel wood used up to 20 suppliers. These suppliers often have more than one crew, but not all crews deliver wood on a daily basis.

\section{Product Delivered Costs}

Each mill was asked to compare their price paid for three types of biomass deliveries: mill residue, urban/municipal waste, and logging residue. The results were not consistent between the seven mills that bought biomass. Two mills did not have a price difference based on the source of the biomass. Four mills placed the lowest price on mill residues. Two mills priced urban/municipal waste highest, while two others priced logging residues as highest. To attempt to compare the price differences given, responses were assigned a value of 1 for the lowest priced product, 2 for the moderate priced product, and 3 for the highest priced product. Mill residues received an average score of 1.14, urban/municipal waste scored 2.14 and logging residue scored 2.00 .

Many reasons were given why there was or was not a difference in prices paid for deliveries. Some incorporated considerations for the cost of processing prior to delivery. Two mills paid more for logging residue because they recognize the machinery and labor requirements needed for this type of operation. These two mills paid less for urban/municipal waste because they believed that less equipment and fewer personnel were needed for the operation. Mill residues were lowest priced because if mills did not deliver the material to them, the supplier would have to pay landfill prices or burn the material to dispose of it. One mill paid an additional premium for walking floor van deliveries, as they recognize the higher cost of the equipment.

Alternatively, two mills paid the most for urban/municipal waste. They preferred tub ground material for the chunk size, and this is a typical type of processing that is used in urban/municipal waste operations in their areas. One mill specifically paid less for urban/municipal waste than logging residue because the material is usually piled and allowed to air dry a little prior to processing. This lower moisture content decreases the value of the product for this mill.

\section{Forest Operations and Mill Specifications}

What can the fuel chip processing operation do to increase the value or decrease the cost of processing hog fuel? If mills have a preference for species, then sorting the material may provide a higher value for the product rather than delivering mixed species biomass. If mills prefer chunkier material, loggers can adjust equipment, using screens or other devices, to meet the size specification. If the material is processed smaller than required, the logging operation may incur unnecessary additional expenses, such as wear and tear on equipment and additional fuel usage. If mills don't have a size specification, contractors should process material to the most efficient size to reduce processing costs and increase the delivered payloads. If mills have a preference for lower moisture content, and are willing to pay for it, operations could allow the material to air dry prior to processing. Opportunities exist to increase the value of the delivered product, but many of these result in additional processing costs.

\section{Summary}

Pulp and paper mills in Alabama buy woody biomass but the specifications required by the mills vary and are not widely known. Some characteristics of woody biomass that are often included 
in mill specifications include size, species and moisture content. These characteristics can impact the energy value, physical handling or processing of the material.

Based on the results of informal structured interviews, mill specifications and quality testing procedures vary between Alabama's pulp and paper mills. Some mills prefer smaller material and others prefer chunkier material. Some mills prefer a higher moisture content in their deliveries, while others prefer drier material. Size specifications were often closely tied to the hog fuel handling processes in mills. None of the mills pay a price difference based on species mix, but the source of the biomass (mill residues, urban/municipal waste or forest residues) was often listed as a factor in determining the delivered prices.

Since the principle driver for the growing interest in woody biomass is energy price, we can expect an increasing interest in attention to fuel chip specifications. When relative energy prices are low, there is little value in demanding specification. However, when relative energy prices increase, there can be significant payback for tracking characteristics that affect net BTUs, like moisture content or species.

\section{References}

Alabama Forestry Association. 2006. Alabama Pulp and Paper Council. Montgomery, AL: Alabama Forestry Association. Available at: http://www.alaforestry.org. Accessed June 8, 2006.

Ince, P.J. 1979. How to estimate recoverable heat energy in wood or bark fuels. USDA For. Serv. GTR 29, For. Prod. Lab., Madison, WI.

Koch, P. 1972. Utilization of the southern pines. USDA Agric. Handb. 420. USDA For. Serv., South. For. Exp. Sta.

Metz, L.J., and Well, C.G. 1965. Weight and nutrient content of the aboveground parts of some loblolly pines. USDA For. Serv. SE-RP-17, Southeast For. Exp. Sta., Asheville, NC.

Muehlenfeld, 2003. Assessment of Wood-Based Syngas Potential for Use in Combined Cycle Power Plants in Alabama: A Guide For Economic Development Opportunities. Tuscaloosa, AL: University Center for Economic Development. Available at: http://www.tallcbiomass.com/image /muehlenfeld_report.pdf. Accessed July 8, 2006. 